\section{INFLUENCE OF LEADERSHIP STYLES TOWARDS ORGANIZATIONAL COMMITMENT}

\author{
Suman A/L Mahindreen \\ University Malaysia Sarawak \\ Qistina Donna Lee Abdullah \\ University Malaysia Sarawak \\ Khashini Devi R. Varatharajoo \\ University Malaysia Sarawak
}

Corresponding Author

dlqistina@unimas.my
This research endeavours to explore the impact of leadership styles towards organizational commitment in influencing employees and employer's outcomes in the context of organizational commitment. Based on this theory, two leadership styles practices, namely, Transformational Leadership and Transactional Leadership, have been used to examine employees' and employer's reactions towards commitment in the organization chosen which is Amogha Maju Sdn Bhd, Kuching, Sarawak. Data were acquired from employees in administrative level through interview questions. Thus, researcher acknowledge that the employees were influenced by Transactional and Transformational Leadership Styles.

Keywords: Leadership, Organizational Commitment, Transactional leadership, Transformational leadership. 


\section{INTRODUCTION}

In an organization, a leader's role is essential in determining the excellence of the organizational performance. The leaders decision influences the followers to be committed in the organization. To build a successful and dynamic organization, competing leader should play their role as a strategic leader in an organization. Leaders should be aware on which type of leadership style that can be a better guidance to influence and motivate the employees. Practicing specific leadership style is one of the important element in an organization serves as a key driver of performance in the organization (Isa, 2013). The problem statement of this research, Roger (2008) claims that transformational leadership style can influence employee's commitment, so that employee's commitment has a positive impact on the organization. Researcher will identify that transactional leadership style also can bring a positive impact to an organization through rewards and punishments.

Transactional leadership style known as managerial leadership, focuses on the role of supervision, organization, and group performance. Leaders who implement this style focus on specific tasks and use rewards and punishments to motivate followers (Cherry, 2017). Transactional leadership influencing the followers mostly by rewards and followers willingly become committed towards the organization. Hence, punishment makes followers strictly follow the instruction given by the leader and it will have effective progressive in organization by practicing transactional leadership style. There are three factors that can be categorized in the transactional leadership style which are contingent rewards, active management and passive management. Contingent reward is about how the leader will identify the expectations of their followers and fulfil their expectations through punishment and rewards (Brahim, Ridic, \& Jukic, 2015). Power is given to the leaders to evaluate, correct and train subordinates when performance needs to be improved and to reward effectiveness when the required outcomes are achieved (Essays, 2018). As for an active management individual, the leader always has solution for any issue before it arises. The leader always pay attention to the followers and keep updating about their progress. As an active management leader, he will easily identify the issues through active involvement of the employees in the organization. Passive management leader's style is the opposite of active management. Passive management will find a solution when there are issues in the organization. In this situation the leader tries to avoid in making the decision earlier.

Organizational commitment is essential for retaining and attracting well qualified workers. Only satisfied and committed workers will be willing to continue their association with the organization and make considerable effort towards achieving its goals (Nagar, 2012). Shin (2017) illustrates that commitment consists of three different aspects: affective, normative, continuance. They describe affective commitment as "a desire", normative commitment as "an obligation", and continuance commitment as "a need" to maintain membership in an organization (p.7). Affective commitment shows that a follower become committed in the organization because of emotional attachments. Next, normative commitment refers to person's feelings of obligation to stay with the organization. In other words, employees remain in the organization because they ought to do so. Moreover, continuance commitment 
is defined as when a follower committed in an organization because of certain reason or benefits.

\section{METHODOLOGY}

This study was conducted at the Amogha Maju Sdn Bhd with a purpose to identify which type of leadership styles influence the employees in the organization and also the impact towards the organization commitments among the employees. Amogha Maju Sdn Bhd has won awards for the best travel and tour services in 2013. In Amogha Maju Sdn Bhd, there are also sub-companies which run actively under the organisation such as Chakra Plantation Sdn Bhd, Lavasthraa Boutique Sdn Bhd, Amogha Properties, and Amogha Tours and Travel Sdn Bhd. Capt (rtd) Narayanan Kanan is the pioneer owner of Amogha Maju Sdn Bhd which is one of a successful company in Borneo. In the initial stage, the researcher focuses on qualitative method by interviewing six selected informants from the organization to support this research to be completed. Five employees of Amogha Maju Sdn Bhd are selected from the Administrative level and one employer from the executive level were interviewed by the researcher. By initiating the in-depth interview, the employees and the employer can give more information from the management insight to support this study. The reason to interview the employer is to identify which type of leadership style practiced by the leader and the interview with the employees is to identify the type of leadership style that influenced the employees to be committed in the organization. Furthermore, researcher used content analysis method to analyse the collected data and information from the organization. According to Bengtsson as cited in Nutriplus (2016), content analysis is a flexible way to analyse the text of data. Non-probability sampling has been used in this study. In detail, purposive sampling is more suitable for this research whereby the researcher purposely select the employees from the administrative level and executive level because these people have stronger communication with leaders in the organization.

\section{RESULTS}

Based on the information given by the informants' in-depth interviews, it has proven that they are practicing leadership role as a leader. The leaders of Amogha Maju Sdn Bhd are the key partners in the organization. The leaders will assign their task by giving instructions to their followers and the followers will make sure the tasks are completed accordingly within allocated timeframe. Informant 1 has mentioned in the interview that staffing is one of the challenges he faced in the organization. To build a dynamic organization, the leader decided to pay more attention to employees working skills. By observing on employees performance, the leader will make decision whether to take further action. The informant also added that the leader of Amogha Maju Sdn Bhd once mentioned that "When it comes to the work, nowadays employees more depend on how much salaries and additional incomes provided by the company. So, I will provide some additional payment in their salary to motivate them be more commitment towards the organization". In addition, the leader also emphasise that he will take an action when the employees do not show any positive changes in terms of commitments after providing all the benefits for the employees. There is a special training 
skill session organized by the organization to improve the employees performance. The training session is fully supported by Amogha Maju Sdn Bhd by giving the opportunity to all of the employees to improve their skills and knowledge apart from upgrading the organization's performance level.

Furthermore, the informants have pointed out that the leaders' communication skill as an important aspect between executive management and administration management in any organization. The leader at Amogha Maju Sdn Bhd always communicate with the employees to motivate them to be more committed towards the organization. Employer advices the employees as well to improve their level of performance. A two-way communication between both management and employer can easily prevent the miscommunications in the organization. It shows a strategic leaders style in managing the organization more effectively.

Moreover, informants also mentioned that the leader will organize an annual dinner for the employees as a token of appreciation for their commitments in the organization. During the dinner event, the leader gives awards for the best employees who are continuously committed in the organization. Furthermore, informants also mentioned that are rewarded with yearly increment every year. In addition, the employer stated that if there is any of employees who is not really committed to the organization, he will have to attend councelling sessions conducted by the leader to solve any issues arised. Hence, "A serious action will be taken by the employer towards the employees if there is no changes in terms of commitments" as informed by the leader to the employees.

Most of the employees are committed to the organization because of specific benefits provided by the leader to the employees. The employer has mentioned that he will support the women employees by giving cash money and other necessary needs after their child birth delivery. Moreover, the employer also provide free medical consultation at specific clinics for their employees. This has encourages the employees to be more committed to the organization. Amogha Maju Sdn Bhd also encourages its employees to increase their level of performance and their progressiveness in the organization. Furthermore, the organization provides free of charge short vacation trip to the employees. The employer emphasis more in this rewards which provides free travel and tour opportunity for the employee who is truly committed to the organization.

\section{DISCUSSION AND CONCLUSION}

There are many ways handled by the strategic leaders which can prove how to influence an employees' commitment towards the organization. As we can clearly see what have been mentioned by the informants during the interview, the employer of Amogha Maju Sdn Bhd practiced transactional leadership style as to increase their progressive performance in the organization. 
During the interview session, the employer has informed to employees that action will be taken by dismissing employees who do not show any improvement after consultation and counselling sessions. The action of the leader is actually to motivate the employees in a strict way. The employer also does not wish to dismiss the employees from the organization since most of the employees in Amogha Maju Sdn Bhd have worked at the organization for more than five years. Their experience and loyalty towards working in Amogha Maju Sdn Bhd might not be fulfilled by other new employees. Furthermore, employees who are continuously committed in the organization by practicing transactional leadership are driven through yearly increment, medical insurances and special training lessons provided by the employer. Rewards and punishments to the employees of Amogha Maju Sdn Bhd are important aspects that easily influenced the employer to become active organization among other organization.

Khan and Adnan (2014) mentioned that in transactional leadership, the leader motivates the employees and encourages positive attitude through rewards and punishment. Transactional leadership can also be seen when the manager motivates the employees to be productive (Essays, 2018). Commitments among the employees in an organization will strengthen the relationship by using transactional leadership style as mentioned by Kalsom, Khan, and Zubair (2018). This statement shows that by practicing transactional leadership, also can employees will be more committed and will help to increase more positive impact to the organization.

In this research, researcher has mainly focus on transactional leadership style. As stated in the problem statement, researcher proves that by practicing transactional leadership style, more positive impact can be seen in the organization. Moreover, employees will also willingly committed to the leader because of the rewards and punishments by the organization.

As a conclusion, the research has proven that employees of Amogha Maju Sdn Bhd are being committed to the organization through transactional leadership style by the leaders in the organization. It has been proved that significant relationship between transactional leadership and organizational commitment in Amogha Maju Sdn Bhd.

\section{REFERENCES}

Bengtsson, M. (2016). How to plan perform a qualitative study using content analysis. Nutriplus, 2(8-14.

Brahim, A. B., Ridic, O., \& Jukic, T. (2015). The effect of transactional leadership on employees performance case study of 5 algerian banking institutions. Journal of Economics and Business, Vol, XIII, Issue 2, 2.

Cherry, K. (2017, May 27). Verywellmind. Retrieved from Transactional leadership: https:// www.verywellmind.com/what-is-transactional-leadership-2795317

Essays, U. (2018, November). Reward and punishment in transactional leadership. Re- 
trieved from https://www.ukessays.com/essays/management/reward-and-punishment-of-transactional-leadership-management-essay.php\#citethis

Isa, K. (2013). The influence of transformational and transactional leadership style towards employee commitment in Malaysia royal customs organization. Journal of Techno Social, 5(2), 54-55.

Kalsom, Z., Khan, M. A., \& Zubair, S. S. (2018 ). Impact of transactional leadership and transformational leadership on emloyee performance: a case of FMCG industry of Pakistan. Industrial Engineering Letters, Vol.8, No.3, 26-26.

Khan, A. Z., \& Adnan, N. (2014). Impact of leadership styles on organizational performance . International journal of management sciences , 504-505.

Nagar, K. (2012). Organizational Commitment and Job Satisfaction among teachers during times of burnout. Vikalpa, Vol 37 No.2.

Shin, Y. (2017). The relationship between leadership styles, organizational commitment and organizational outcome in Oklahomas volunteer fire department. Shareok Repository, 7. 